\title{
Foraging behaviour of American oystercatchers in response to declining prey densities
}

\author{
Joanne Tuckwell and Erica Nol
}

\begin{abstract}
American oystercatchers (Haematopus palliatus) responded to declines in the density of oysters (Crassostrea virginica) on a commercial oyster bed examined in 1979 and 1995 by increasing the number of species of prey eaten and search times, but not peck rates or handling times. Seasonal changes in foraging behaviour included oystercatchers choosing larger oysters with longer handling times in winter than in autumn, but with subsequently greater profitability and higher intake rates. Time budgets of foraging birds were similar in the two seasons. Oystercatchers ate fewer mussels in winter than in autumn, and fewer mussels than oysters at all times. Search and handling times for mussels were similar in autumn of the 2 years. After a commercial harvest of oysters at a second site, handling times for oysters did not decline; however, search times were significantly more variable, niche breadth was greater, and there was a trend towards longer search times post harvest. The recorded changes in foraging behaviour indicated a close match between search and handling times and prey density and size and behavioural flexibility of foraging birds in response to sometimes drastic changes in their prey base.
\end{abstract}

\begin{abstract}
Résumé : Les Huîtriers d'Amérique (Haematopus palliatus) ont réagi à la diminution du nombre d'huîtres (Crassostrea virginica) dans une huîtrière commerciale examinée en 1989 et en 1995 en consommant un plus grand nombre d'espèces de proies et en augmentant la durée de leur recherche, mais ils n'ont augmenté ni la fréquence de leurs coups de bec, ni la durée de manipulation de leurs proies. Parmi les changements saisonniers observés dans le comportement de recherche de nourriture des oiseaux, nous avons constaté qu'ils choisissaient de plus grosses huîtres et les manipulaient plus longtemps en hiver qu'à l'automne, mais en tiraient plus de profit et augmentaient leurs taux d'ingestion. Les budgets temporels des oiseaux à la recherche de nourriture étaient semblables au cours des deux saisons. Les huîtriers consommaient moins de moules en hiver qu'à l'automne, et moins de moules que d'huîtres en tout temps. La durée de la recherche et celle de la manipulation de la nourriture se sont avérées les mêmes au cours de deux automnes. Après la récolte commerciale des huîtres à un second site, la durée de manipulation des huîtres n'a pas diminué, mais la durée de la recherche des proies est devenue beaucoup plus variable, la largeur de la niche a augmenté et la durée de la recherche avait tendance à augmenter. Les modifications du comportement de recherche de nourriture indiquent une paritié étroite entre la durée des manipulations et la durée de la recherche des proies, entre la densité des proies et leur taille, et démontrent la flexibilité des huîtriers face à des changements considérables de leur source de proies.

[Traduit par la Rédaction]
\end{abstract}

\section{Introduction}

Long-term changes in prey density occurring as a result of parasitic disease can alter the foraging behaviour of wintering shorebirds, through a switch to new feeding sites or new prey (Goss-Custard and Durell 1983) or an increase in the time devoted to feeding (Boates and Goss-Custard 1992). Seasonally, prey behaviour can be affected by temperature (Woodin 1974; Conners et al. 1981; Zwarts and Wanink 1993), so that at lower temperatures, prey decrease in size and (or) density or become less available and shorebirds become energetically stressed (Dugan 1981; Davidson 1981; Davidson and Evans 1983; Hulscher 1989). Shorebirds relying on commercially harvested shellfish must also respond to

Received May 9, 1996. Accepted August 27, 1996.

J. Tuckwell' and E. Nol. ${ }^{2}$ Watershed Ecosystems Graduate Program, Trent University, Peterborough, ON K9J 7B8, Canada.

Present address: 521 Kelvin Boulevard, Winnipeg, MB R3P 0T2, Canada.

2 Author to whom all correspondence should be addressed (e-mail: enol@trentu.ca). the depletion of prey through behavioural shifts to overcome potential energy deficits. Altering search times (Piersma et al. 1995), handling times (Kaspari and Joern 1993), and intensity of the search (Cayford and Goss-Custard 1990; Cresswell 1994) in response to changes in prey populations over time leads to alterations in profitability (grams per unit handling time; Stephens and Krebs 1986) and overall intake rates (grams per unit total foraging time) for particular prey species (Cayford and Goss-Custard 1990; Goss-Custard et al. $1995 a, 1995 b)$.

American oystercatchers (Haematopus palliatus) are highly visible shorebirds that forage on large, visible prey (Nol 1989). Its European counterpart, $H$. ostralegus, has been the subject of a wide range of papers describing the relationship of this bird to its bivalve molluscan prey (see Hulscher and Ens 1992; Ens et al. 1992; Goss-Custard et al. 1995a, 1995b). By contrast, the feeding ecology of the American oystercatcher is poorly known (Levings et al. 1986; Nol and Humphrey 1994). The American oystercatcher winters in large flocks comprising both resident and migrant birds along the coasts of Virginia and North Carolina (Nol and Humphrey 1994), where it forages primarily on commercially harvested oysters (Crassostrea virginica; Cadman 1980). 
We report the results of a study designed to examine the consequences of changes in prey abundance from three sources, long term, seasonal, and preharvest and post harvest, for the foraging behaviour of wintering American oystercatchers in Virginia. Commercially seeded oyster beds in this region have been devastated by three parasites (Haplosporidium nelsoni, $H$. costale, and Perkinsus marinus) and overharvesting since the 1970s (Sindermann 1970; Haskin and Andrews 1988; Andrews 1988; Figueras and Fisher 1988). We use an older study (Cadman 1980) as the basis of our long-term comparison. Seasonal declines in oyster abundance are due primarily to predation by oystercatchers in autumn and winter. We also report on changes in the behaviour of foraging oystercatchers on a commercial oyster bed following a harvest of oysters in summer 1994.

Specific predictions about changes in foraging behaviour include an increase in search time in all three comparisons for birds that continue to forage on oysters after the decline, a decrease in handling time in response to a decline in prey size (Holling 1959; Piersma et al. 1995), and changes in peck rate that reflect changes in the distribution and abundance of alternative prey. We also predicted that oystercatchers would spend more time foraging overall when prey densities were lower (Maron and Myers 1985; Martin 1986), or switch to alternative prey (Frank 1982). For the seasonal and pre- and post-harvest comparisons we also examined he consequences of changes in prey abundance and predator behaviour or intake rates and profitability of prey of foraging oystercatchers.

\section{Study areas and methods}

\section{Study areas}

This study was conducted during three time periods: OctoberDecember 1993, October-December 1994, and 7-15 February 1995. Most observations were made in one of three locations, with short trips made on a regular basis to locate oystercatchers foraging or roosting elsewhere in the region. The main study area, Queen Sound (Fig. 1), is located $5 \mathrm{~km}$ west of the island of Chincoteague, Virginia $\left(37^{\circ} 56^{\prime} \mathrm{N}, 75^{\circ} 28^{\prime} \mathrm{W}\right)$. Salt marshes, channels, bays, mud flats, sand flats, and oyster beds characterize the area. The dominant vegetation of the salt marshes consists of salt hay (Spartina patens), smooth cordgrass (Spartina alterniflora), and saltwort (Salicornia sp.). The Queen Sound oyster bed is manmade, and consists of American oysters that were last seeded in the summer of 1993 and ribbed mussels (Geukensia demissa) that grow wild and are considered a nuisance by the local oyster harvesters (D. Thornton, personal communication). The bed is located in the intertidal zone at the north end of a large shallow bay and is exposed by the tide twice each day, the exposure time depending on moon phase and wind speed and direction (range $0-12 \mathrm{~h}$ ).

The secondary study site (hereafter referred to as the sand flat) is a sand flat approximately $3 \mathrm{~km}$ south of the Queen Sound oyster bed (Fig. 1). It was accessible by boat during the autumn months (November and December) and was chosen as a study site because of the large numbers of oystercatchers seen there daily. Possible prey types found in the sandy mud were common razor clams (Ensis directus), stout razor clams (Tagelus plebeius), northern quahog (Mercenaria mercenaria), and various worms (Clymenella torquata and Glycera spp.).

A third study site was located off the coast of Wachapreague, Virginia $\left(37^{\circ} 36^{\prime} \mathrm{N}, 75^{\circ} 41^{\prime} \mathrm{W}\right), 70 \mathrm{~km}$ south of Chincoteague. This site was chosen because in autumn 1994 it was thought that it would provide temporal control for the historical comparison, as it was con- sidered to be a site with a healthy oyster population (M. Luckenbach, Virginia Institute of Marine Sciences, personal communication). It consists of a commercial oyster bed located at the tip of a large sand flat containing common razor clams, stout razor clams, northern quahog, and worms. The oyster bed, accessible only by boat during low autumn tides, is composed of American oysters, ribbed mussels, and worms in the mud surrounding the bivalves. This bed was harvested in summer 1994, leaving fewer oysters for the second autumn field season. Therefore, we use it as an example of the response of oystercatchers to a rapid decline in preferred prey availability.

The average temperature during autumn 1993 was $10.1^{\circ} \mathrm{C}$, the minimum temperature being $-1.7^{\circ} \mathrm{C}$ and the maximum $27.8^{\circ} \mathrm{C}$. The average temperature during autumn 1994 was $12.2^{\circ} \mathrm{C}$, with a minimum of $-3.3^{\circ} \mathrm{C}$ and a maximum of $25.0^{\circ} \mathrm{C}$. The average for February 1995 was $-1.2^{\circ} \mathrm{C}$, with a minimum of $-10.0^{\circ} \mathrm{C}$ and a maximum of $11.1^{\circ} \mathrm{C}$.

\section{Observation periods}

Boat trips to the sand flat were made whenever wind and weather permitted in the autumn. In total, 16 trips were made, 6 in 1993 and 10 in 1994 . Only one trip was made to the sand flat in winter 1995. On each trip other sites were also visited in an attempt to locate oystercatchers foraging or roosting elsewhere. We made a total of 10 trips to the Wachapreague site, 4 in 1993 and 6 in 1994. The remainder of the study period was spent at the Queen Sound oyster bed. Whenever possible (e.g., no heavy rains) we visited the sites for the entire daylight period. Five nightly trips, each $1 \mathrm{~h}$ in duration, were made each season, during clear nights, sometimes with a full moon, to determine if nocturnal foraging was taking place at the Queen Sound oyster bed.

\section{Prey characteristics}

Oyster density and size were measured at the Queen Sound oyster bed to determine how oyster populations had changed seasonally and historically, and at the Wachapreague bed to determine how the oyster population had changed after the harvest in summer 1994. We sampled the Queen Sound oyster bed each year and the Wachapreague oyster bed in 1993 and 1994, by randomly placing 25-70 quadrats measuring $25 \times 25 \mathrm{~cm}$ on the bed, counting the bivalves in each quadrat, and measuring each bivalve. This quadrat size was chosen because it was also used by Cadman (1980), and the oysters, because they were seeded, were distributed relatively evenly over the bed. Shell heights of mussels and oysters were measured to $\pm 0.01 \mathrm{~mm}$ using calipers. The flesh was extracted from all oysters and mussels in the quadrats and the volume of this flesh was measured by water displacement to the nearest $0.5 \mathrm{~mL}$. At the Wachapreague site, five core samples (diameter $30 \mathrm{~cm}$; depth $1.0 \mathrm{~m}$ ) of mud surrounding the oyster bed were extracted for the purpose of identifying the invertebrate species present. No estimations of prey density were made at the sand flat location near Queen Sound.

\section{Time budgets}

The amount of time spent foraging, roosting, flying, or preening each day was calculated at the Queen Sound oyster bed each season. The time budget of all oystercatchers within view, during times when the beds were exposed at each location, was recorded once every $10 \mathrm{~min}$ (i.e., instantaneous scan samples) at the Queen Sound oyster bed for 1 week in 1993, 2 weeks in 1994, and 9 days in winter 1995, and for 11 days in autumn of both years (1993 and 1994) at the sand flat. The daily percentages of birds foraging, roosting, preening, and flying were averaged for each location and considered to be representative of the time each activity was performed each day. 
Fig. 1. The eastern shore of Virginia, indicating the location of Chincoteague Island. Inset: Map of the study area surrounding Chincoteague. 1, Queen Sound oyster bed; 2, high-water roost; 3, Chincoteague Island.

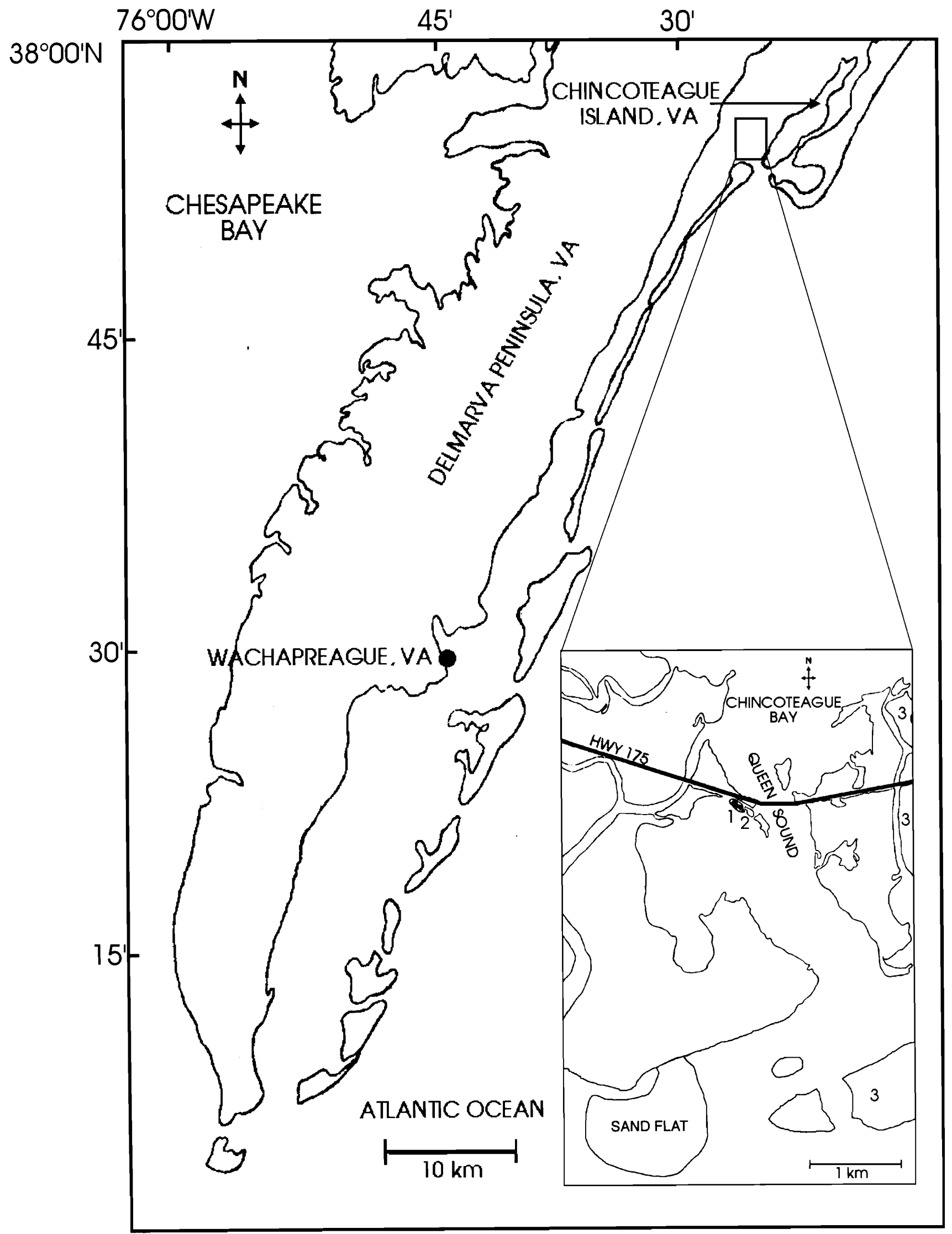


Table 1. Historical, yearly, and seasonal changes in oyster density at the Queen Sound oyster bed and post-harvest changes at Wachapreague.

\begin{tabular}{|c|c|c|c|c|}
\hline Comparison & $N$ & $\begin{array}{c}\text { Mean no. of } \\
\text { oysters } / 0.0625 \mathrm{~m}^{2}\end{array}$ & $t_{\mathrm{s}}^{*}$ & $P$ \\
\hline \multicolumn{5}{|c|}{ Queen Sound } \\
\hline \multicolumn{5}{|l|}{ Historical } \\
\hline Winter $1979^{\dagger}$ & 64 & $47.54(4.79)$ & 9.09 & $<0.0001$ \\
\hline Winter 1995 & 30 & $3.73(0.52)$ & & \\
\hline \multicolumn{5}{|l|}{ Yearly } \\
\hline Autumn 1993 & 50 & $7.12(0.64)$ & 1.08 & 0.28 \\
\hline Autumn 1994 & 50 & $9.04(1.05)$ & & \\
\hline \multicolumn{5}{|l|}{ Seasonal } \\
\hline Autumn (2 years) & 100 & $8.08(0.62)$ & 4.05 & 0.0001 \\
\hline Winter 1995 & 30 & $3.73(0.52)$ & & \\
\hline \multicolumn{5}{|c|}{ Wachapreague } \\
\hline Preharvest (autumn 1993) & 16 & $10.81(1.52)$ & 2.98 & 0.003 \\
\hline Post harvest (autumn 1994) & 25 & $3.24(0.67)$ & & \\
\hline
\end{tabular}

Note: Numbers in parentheses are standard errors. $N$ is the number of quadrats.

*Significance was tested using Wilcoxon's rank-sum test.

${ }^{\dagger}$ From Cadman (1980).

\section{Foraging parameters and prey choices}

We arbitrarily chose and observed a foraging oystercatcher until three successful foraging bouts were completed. During this period one of us (J.T.) noted the prey type and determined search and handling times and peck rate for each prey item, using a stopwatch. Prey consisted primarily of mussels or oysters, which were easily identifiable. The number of oystercatchers foraging and the state of the tide (rising or falling) were recorded at the beginning of each new observation.

Search time was defined as the time taken from the completed consumption of one prey item to the successful search for another (Cadman 1980). Handling time was recorded from the initial dartprobe action of the oystercatcher until the beginning of another search time. Bivalve flesh was often loose in an already opened shell and the bird could extract it in less than $3 \mathrm{~s}$, in which case we recorded it as scavenging and not as a successful foraging bout. We defined a peck as the touching of the substrate with the tip of the bill. The peck rate was the number of pecks made during a 10-s period.

An oyster or mussel was usually extracted in more than one piece, and we refer to each piece as a bite. Using the dimensions of the oystercatcher's bill we estimated the size of each bite and allocated it to one of three size classes. The largest, class 3 (oysters $>6.0 \mathrm{~mL}$ (midpoint $6.0 \mathrm{~mL}$ ); mussels $>10 \mathrm{~mL}$ (midpoint $10.0 \mathrm{~mL}$ )), for both bivalves was usually hard to swallow and the meat was as long as the bill (about $86 \mathrm{~mm}$; Nol and Humphrey 1994). When an oystercatcher swallowed a bite smaller than one-quarter of the bill length, we considered it to be a class 1 bite (oysters $<0.99 \mathrm{~mL}$ (midpoint $0.5 \mathrm{~mL}$ ); mussels $<1.99 \mathrm{~mL}$ (midpoint $1.0 \mathrm{~mL}$ )). A class 2 bite (oysters $1-5.99 \mathrm{~mL}$ (midpoint $3.5 \mathrm{~mL}$ ); mussels 2-9.99 $\mathrm{mL}$ (midpoint $6.0 \mathrm{~mL}$ )) was somewhere in between; we based this class on relative bill dimensions. Pieces of flesh of various sizes, from very small to very large, were cut by an assistant and their volumes were measured by water displacement to the nearest $0.5 \mathrm{~mL}$. The accuracy of judging bite size was determined by having the assistant hold up these pieces of flesh to a model oystercatcher placed on the Queen Sound oyster bed (Goss-Custard et al. 1987). While sitting at the usual observation point in a car, we assigned each piece of flesh to the size class we thought correct. Accuracy was determined to be $100 \%$ when estimations of size class were compared with the actual volume of each piece of flesh.
We estimated the total volume of the oyster or mussel eaten by each oystercatcher by summing the midpoint estimates of the individual bite size classes.

Caloric values were obtained from the literature as follows: Mytilidae (128.8 kJ $\cdot \mathrm{g}^{-1}$ dry mass; Cummins and Wuycheck 1971); American oysters $\left(141.8 \mathrm{~kJ} \cdot \mathrm{g}^{-1}\right.$ dry mass; Dame 1972); and Annelida (109.5 kJ $\cdot \mathrm{g}^{-1}$ mass; Cummins and Wuycheck 1971).

\section{Statistical analysis}

All data were tested for normality, and if they were not normal, then nonparametric statistics were used. Arcsine transformations were performed on time-budget data. As a long-term comparison, winter 1995 foraging behaviour data and oyster densities were compared with these variables provided by Cadman (1980), as his study was also done during the winter, from 7 January to 8 March 1979. Direct comparisons with volumes and the variables that depend on volume (intake rates and profitability) found by Cadman (1980) were not made because the class sizes used to estimate bite size differed. We also did not compare statistically the numbers of birds foraging in winter 1995 with the numbers in 1979 because of the absence of standard errors in Cadman (1980). The evenness measure of the Shannon-Wiener function (Krebs 1989) was used to compare diet breadths in the long-term comparison and seasonally.

Prior to any statistical analyses, search times, handling times, and peck rates were averaged according to prey type (oyster or mussel) for each bird observed, to avoid pseudoreplication (Hurlbert 1978; Heijl et al. 1990). Means are given plus or minus 1 standard error and probabilities less than $5 \%(P<0.05)$ are considered significant, although exact probabilities are reported.

\section{Results}

\section{Prey characteristics}

Oyster densities at the Queen Sound oyster bed in autumn of 1993 and 1994 were not significantly different and these data were pooled (Table 1). The oyster density at this bed was significantly lower in winter 1995 than in autumn 1995 and in 1979 (Cadman 1980). The density of oysters at the 
Fig. 2. Time budgets for oystercatchers at the Queen Sound oyster bed in autumn 1994 and winter 1995, and at the sand flat in autumn 1994. Vertical bars represent +1 SE. The numbers above the bars represent the number of days on which the activity was recorded.

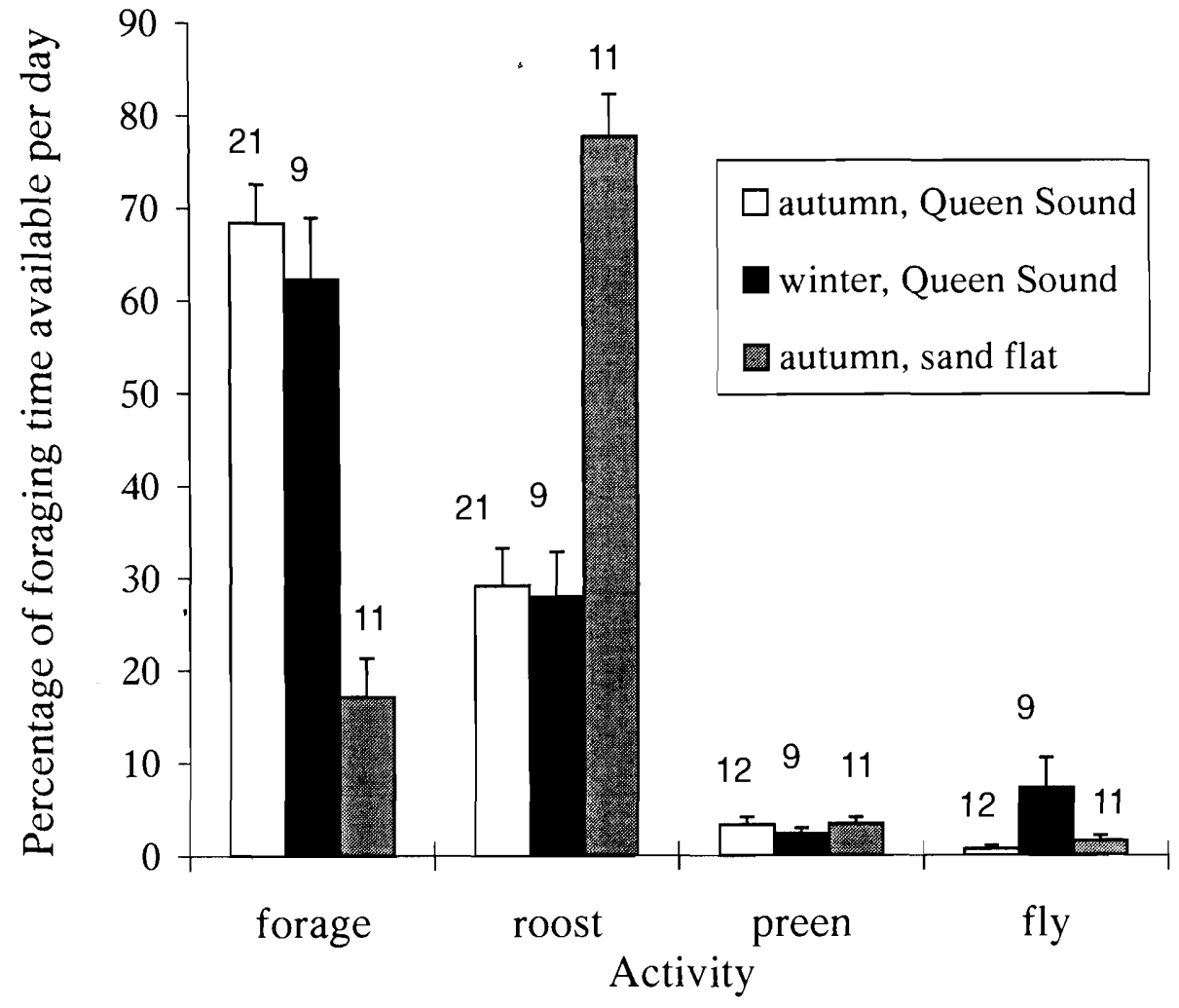

Wachapreague oyster bed was also significantly lower post harvest than preharvest.

Mussel densities (number/0.0625 $\mathrm{m}^{2}$ ) also did not differ significantly between autumn field seasons (1993 $(\bar{x} \pm \mathrm{SE})$ : $4.28 \pm 0.63, n=70$ quadrats; $1994: 5.10 \pm 0.70, n=50$; $t=1.21, P=0.23$ ). The density of mussels was significantly higher in autumn than in winter (autumn (2 years): $4.62 \pm$ $0.47, n=120$; winter 1995: $0.20 \pm 0.15, n=30 ; t=7.82$, $P<0.0001)$. No mussels were counted or noted on the Queen Sound bed in 1979 (Cadman 1980).

On the Queen Sound bed, oysters had a significantly greater height in autumn 1993 than in winter 1995 (autumn $(\bar{x} \pm \mathrm{SE}): 62.5 \pm 1.88 \mathrm{~mm}, n=83$; winter: $47.7 \pm 1.46 \mathrm{~mm}$, $n=69 ; t=6.24, P<0.0001)$. The winter value could not be compared statistically with the height of oysters found in $1979(\bar{x}=41.32 \mathrm{~mm})$ because no standard errors were provided, but the means are quite similar for the two winter field seasons. We were not able to measure the sizes of oysters at Wachapreague.

At the sand flat study area, oystercatchers were seen eating small jackknife clams (Solen viridis), common razor clams, stout razor clams, and small worms that could not be identified by sight. At the Wachapreague oyster bed, core samples contained worms buried in the mud surrounding the oysters, including bamboo worms (Clymenella torquata), large fringed worms (Cirriformia grandis), and blood worms (Glycera spp.).

\section{Time budgets}

The average maximum numbers of birds foraging per day at the Queen Sound oyster bed in 1993 and 1994 did not differ significantly (autumn $1993(\bar{x} \pm \mathrm{SE}): 10.7 \pm 1.27, n=$
24 days; autumn 1994: $14.8 \pm 1.33, n=28$ days; $t_{\mathrm{s}}=1.73$, $P=0.083$ ). The combined numbers were significantly lower than the number of birds foraging on the Queen Sound bed in winter (combined autumn seasons: $12.9 \pm 0.96, n=52$; winter 1995: $\left.44.2 \pm 8.86, n=9 ; t_{\mathrm{s}}=2.61, P=0.009\right)$. In winter 1979 the average daily maximum number of oystercatchers on the Queen Sound bed was 47, and the largest number of birds foraging at one time was 115. In 1995 these numbers were 44 and 74 , respectively. The numbers could not be compared statistically.

More oystercatchers (minimum 4, maximum 53, 16 trips) in the Chincoteague area appeared to forage on the sand flat during autumn than during winter, when only 5 individuals were found foraging on the sand flat (1 trip).

Oystercatchers foraging at the Queen Sound oyster bed during autumn and winter had similar time budgets (Fig. 2). Birds at the sand flat spent significantly more of their day roosting and significantly less time foraging than those at the Queen Sound oyster bed (Tukey - Kramer multiple comparison test, $P<0.05$ ). Birds on the oyster bed spent significantly more time flying during winter than in autumn $(P<0.05)$. During 2 days of extremely low temperatures $\left(-3.9\right.$ and $-4.4^{\circ} \mathrm{C}$ ) and strong northwest winds in the winter of 1995 , oystercatchers remained on the roost even when the Queen Sound oyster bed was exposed. During $15 \mathrm{~h}$ of night observations we never observed foraging, although tides were low, light levels were generally high (from a full moon), and skies were clear.

Diet breadth and prey volume

Oystercatchers ate both mussels and oysters in autumn, but 
Fig. 3. Oystercatcher diet breadth in the Chincoteague area in winter 1979 (Cadman 1980), autumn 1993 and autumn 1994 combined, and winter $1995(a)$, and at Wachapreague in autumn 1993 and autumn $1994(b)$. Numbers above the bars represent the number of observations.
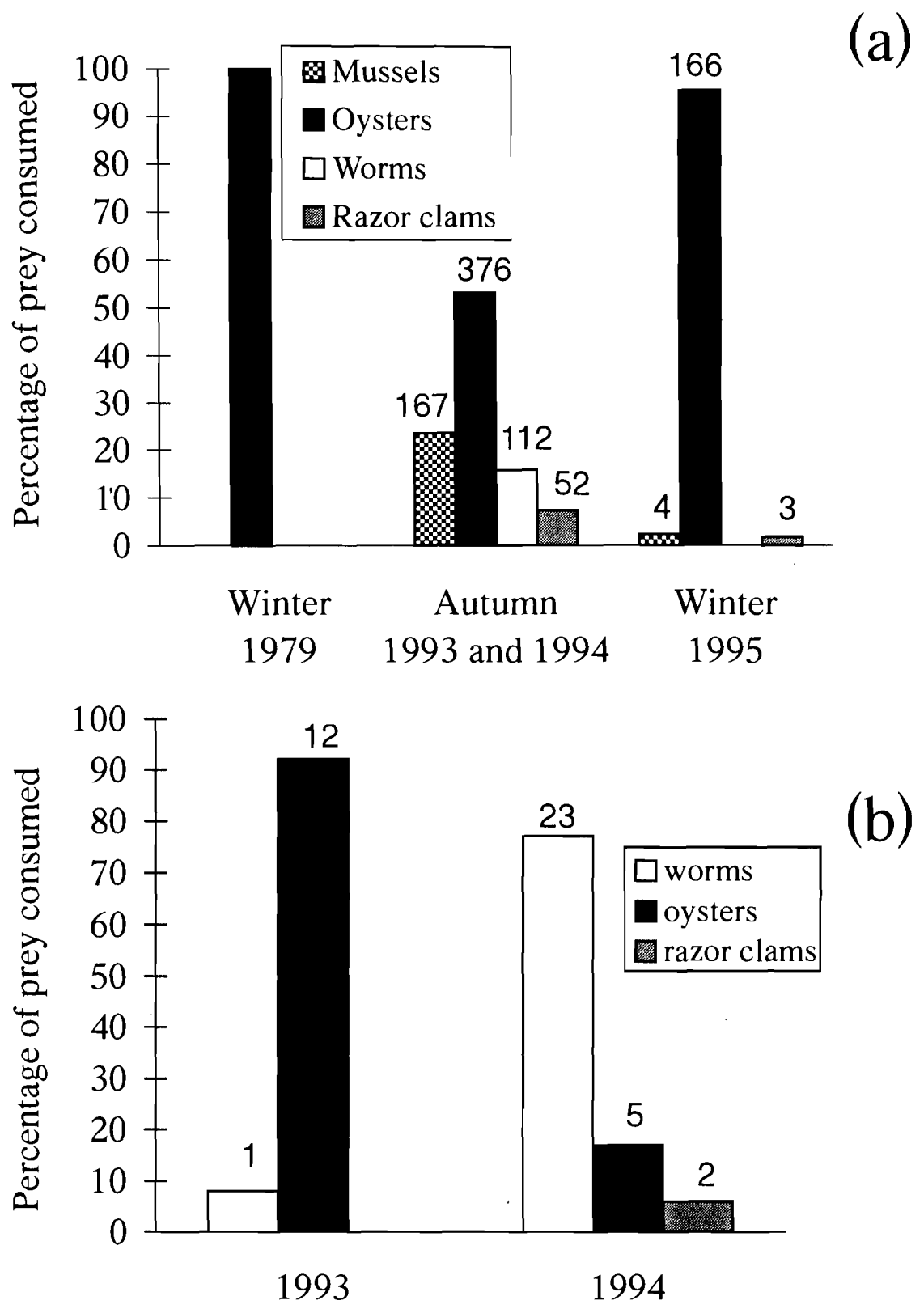

foraged almost completely on oysters during winter. Evenness values calculated using the Shannon-Wiener function resulted in a maximum diet breadth for oystercatchers foraging in the Chincoteague area (Queen Sound plus sand flats) in autumn $\left(J^{\prime}=0.677\right.$ in autumn 1993; $J^{\prime}=0.735$ in autumn 1994), an intermediate diet breadth in winter 1995 $\left(J^{\prime}=0.122\right)$, and zero in winter 1979 , when only oysters were consumed (Fig. 3a). The niche breadth for oystercatchers foraging near Wachapreague was higher post harvest than preharvest $\left(J^{\prime}=0.37\right.$ and $J^{\prime}=0.20$, respectively). In 1993 at Wachapreague we observed oystercatchers consuming only oysters and worms, but in 1994 their diet also consisted of razor clams from the surrounding sand (Fig. 3b).

The average volumes of oysters consumed by oyster- (a)

(b) catchers at the Queen Sound bed were similar in 1993 and 1994, but the combined autumn mean was significantly smaller than the average volume of oysters consumed in winter (Table 2). The average volumes of mussels chosen in the two autumn seasons did not differ significantly.

\section{Foraging behaviour: prey choice as a function of tidal state}

In autumn, given a choice, oystercatchers ate more oysters than mussels. In autumn of both years, they chose mussels at a higher rate during rising tides than during falling tides (1993: 101 oysters and 38 mussels during rising tides; 324 oysters and 41 mussels during falling tides; $G=18.14, P<0.001$; 1994: 68 oysters and 30 mussels during rising tides; 206 oys- 
Table 2. Yearly and seasonal changes in oyster volume and yearly changes in mussel volume chosen by oystercatchers at the Queen Sound oyster bed.

\begin{tabular}{|c|c|c|c|c|}
\hline Comparison & $N$ & $\begin{array}{c}\text { Mean vol. } \\
\text { (mL) }\end{array}$ & $t_{\mathrm{s}}$ & $P$ \\
\hline \multicolumn{5}{|c|}{ Oysters } \\
\hline \multicolumn{5}{|l|}{ Yearly } \\
\hline Autumn 1993 & 123 & $2.31(0.13)$ & 0.48 & 0.63 \\
\hline Autumn 1994 & 119 & $2.39(0.13)$ & & \\
\hline \multicolumn{5}{|l|}{ Seasonal } \\
\hline Autumn (2 years) & 242 & $2.35(0.09)$ & 7.48 & $<0.0001$ \\
\hline Winter 1995 & 159 & $4.20(0.51)$ & & \\
\hline \multicolumn{5}{|c|}{ Mussels } \\
\hline \multicolumn{5}{|l|}{ Yearly } \\
\hline Autumn 1993 & 53 & $6.83(0.60)$ & -0.28 & 0.78 \\
\hline Autumn 1994 & 28 & $6.41(0.74)$ & & \\
\hline
\end{tabular}

Note: Numbers in parentheses are standard errors. $N$ is the number of individuals.

ters and 22 mussels during falling tides; $G=20.71, P<$ 0.001 ; the effect was not significantly different between years, $G=1.27, P=0.74$ ).

\section{Foraging behaviour: search times, handling times, and peck rates}

Search times for oysters on the Queen Sound oyster bed in winter 1995 were significantly longer than search times recorded in 1979 (Table 3). Neither handling times nor peck rates in winter 1979 differed significantly from values collected in winter 1995.

Search times, handling times, and peck rates for oysters did not differ significantly between 1993 and 1994 (Table 4). Search times and peck rates for oysters were significantly greater in autumn than in winter, while handling times were significantly shorter in autumn than in winter.

For mussels, search times were significantly longer in 1994 than in 1993, but mussel handling times and peck rates did not differ between years (Table 5). In autumn, search times were marginally longer for mussels than for oysters, whereas handling times were much longer (search times: $t=1.74, P=0.084$; handling times: $t=10.4, P<0.0001$ ), although peck rates were not significantly different for the two prey types $(t=0.11, P=0.91)$. There were too few observations of oystercatchers foraging on mussels in winter to allow these values to be compared with those for oystercatchers foraging on oysters in winter.

The search times for oystercatchers foraging on the Wachapreague bed, for all prey items, were significantly shorter post harvest than preharvest. However, none of the foraging behaviours described specifically for oystercatchers foraging on oysters (for our relatively small sample in 1994) varied as a result of the harvest (Table 6). Search times were more variable in 1994 than in $1993\left(F_{\max }=6.27, P<\right.$ 0.05 ), and appeared to be slightly longer, on average, in 1994. Handling times for all prey types combined declined significantly, presumably because of the change from oyster to worm prey.

\section{Profitability and intake rates}

The mean intake rates $\left(\mathrm{mL} \cdot 5 \mathrm{~min}^{-1}\right.$ observation time) of oysters at the Queen Sound bed did not differ between 1993 and 1994, but were significantly less in autumn than in winter (Table 7). At Wachapreague, intake rates for oystercatchers eating oysters also declined significantly post harvest. The intake rate for mussels was significantly higher in autumn 1993 than in both autumn 1994 and winter 1995. The overall intake rate at Queen Sound (including both mussels and oysters) was over twice as high in winter 1995 than in autumn of either year (autumn ( 2 years combined): $3.61 \pm 0.26$; winter 1995: $11.72 \pm 0.91 ; t=9.49, P<0.0001$ ).

At Queen Sound the profitability of oysters was significantly greater than that of mussels in autumn of both years (oysters $\left(\mathrm{mL} \cdot \mathrm{s}^{-1}\right.$ handling time): $0.12 \pm 0.004, n=226$; mussels: $0.08 \pm 0.009, n=68 ; t=5.57, P<0.0001$ ), whereas neither oyster nor mussel profitability changed between the two autumn seasons (Table 8 ). We do not have the data to permit a comparison of profitability of eating mussels and oysters in winter. The profitability of oysters was significantly greater in winter 1995 than in the two autumn seasons combined.

\section{Discussion}

\section{Long-term changes}

The long-term decrease in oyster density in coastal Virginia from the 1970s through the 1990s resulting from the combined effects of three parasites has reduced the remaining oyster harvest to a fringe economic activity (from $>1$ million bushels per year in the 1970s to <60 bushels in 1993 and 1994; J. Wesson, personal communication). Coinciding with these changes was an increase in the diet breadth of wintering oystercatchers. Presumably in response to the decline of the oysters, the ribbed mussel, a species not suitable for commercial exploitation, has increased in numbers on the mussel beds, and is now consumed, at least part of the time, by wintering oystercatchers. The lower profitability of this species, caused by a 5-fold increase in handling times, is probably why it is chosen less often than oysters. Oystercatchers at some breeding sites in the Chincoteague area feed their young almost exclusively on ribbed mussels (Nol 1989), so it may be that mussels contain important nutrients that are not provided by the flesh of the American oysters. In addition, the aerobic respiration of ribbed mussels requires them to remain gaping and available for predation during dry conditions (Lent 1968), whereas American oysters close up tightly to avoid desiccation during dry conditions (Shick et al. 1988), and this may explain the consumption of some mussels despite their lower profitability.

A second change in the foraging behaviour of oystercatchers observed from 1979 to 1995 appeared to be an increase in the number of locations over which they foraged. In 1979, Cadman (1980) did not observe oystercatchers foraging anywhere but the Queen Sound oyster bed, and on the bed they ate only American oysters. Although densities of oystercatchers remained similar on the oyster beds over this period, a few oystercatchers foraged on local sand flats in winter 1995. Given the disproportionate effect of cold in lowering the accessibility of burying bivalves (Drew 1907; Kanwisher 1955; Roberts et al. 1988; Zwarts and Wanink 
Table 3. Historical changes in mean search time, handling time, and peck rate for oysters at the Queen Sound oyster bed.

\begin{tabular}{lrrrrrr}
\hline \multicolumn{1}{c}{ Comparison } & Winter 1995 & $N$ & Winter 1979* & $N$ & \multicolumn{1}{c}{$t_{\mathrm{s}}$} & $P$ \\
\hline Search times (s) & $60.87(5.00)$ & 151 & $44.35(2.1)$ & 511 & 2.33 & 0.02 \\
Handling times (s) & $29.55(1.55)$ & 150 & $31.98(1.93)$ & 1358 & 0.70 & 0.48 \\
Peck rates (no. of pecks/10 s) & $0.84(0.04)$ & 141 & $1.52(0.40)$ & 221 & 1.54 & 0.14 \\
\hline
\end{tabular}

Note: Numbers in parentheses are standard errors. $N$ is the number of individuals.

*From Cadman (1980).

Table 4. Yearly and seasonal changes in search time, handling time, and peck rate for oysters at the Queen Sound oyster bed.

\begin{tabular}{|c|c|c|c|c|}
\hline Comparison & $N$ & Mean & $t_{\mathrm{s}}$ & $P$ \\
\hline \multicolumn{5}{|c|}{ Search time (s) } \\
\hline \multicolumn{5}{|l|}{ Yearly . } \\
\hline Autumn.1993 & 111 & $72.03(5.03)$ & -1.47 & 0.14 \\
\hline Autumn 1994 & 111 & $94.78(9.44)$ & & \\
\hline \multicolumn{5}{|l|}{ Seasonal } \\
\hline Autumn (1993 and 1994) & 222 & $83.41(5.39)$ & -4.39 & 0.0001 \\
\hline Winter 1995 & 151 & $60.87(5.00)$ & & \\
\hline \multicolumn{5}{|c|}{ Handling time (s) } \\
\hline \multicolumn{5}{|l|}{ Yearly } \\
\hline Autumn 1993 & 111 & $19.98(0.86)$ & -0.70 & 0.48 \\
\hline Autumn 1994 & 109 & $23.51(1.84)$ & & \\
\hline \multicolumn{5}{|l|}{ Seasonal } \\
\hline Autumn (1993 and 1994) & 220 & $21.73(1.02)$ & 5.39 & $<0.0001$ \\
\hline Winter 1995 & 150 & $29.55(1.55)$ & & \\
\hline \multicolumn{5}{|c|}{ Peck rate (no. of pecks/10 s) } \\
\hline \multicolumn{5}{|l|}{ Yearly } \\
\hline Autumn 1993 & 111 & $1.25(0.04)$ & -1.51 & 0.13 \\
\hline Autumn 1994 & 94 & $1.24(0.08)$ & & \\
\hline \multicolumn{5}{|l|}{ Seasonal } \\
\hline Autumn (1993 and 1994) & 205 & $1.24(0.04)$ & -6.30 & $<0.0001$ \\
\hline Winter 1995 & 141 & $0.84(0.04)$ & & \\
\hline
\end{tabular}

Note: Numbers in parentheses are standard errors. $N$ is the number of individuals.

Table 5. Yearly changes in mussel search time, handling time, and peck rate at the Queen Sound oyster bed.

\begin{tabular}{lcccccrrr}
\hline & \multicolumn{2}{c}{1993} & & \multicolumn{2}{c}{1994} & & & \\
\cline { 2 - 3 } & Mean & $N$ & & Mean & $N$ & & \multicolumn{1}{c}{$t_{\mathrm{s}}$} & $P$ \\
\hline Search time (s) & $82.5(9.21)$ & 48 & $137.08(20.13)$ & 32 & 2.16 & 0.03 \\
Handling time (s) & $97.67(6.04)$ & 44 & $99.67(11.68)$ & 27 & -0.03 & 0.98 \\
Peck rate (no. of pecks/10 s) & $1.20(0.09)$ & 47 & & $1.36(0.17)$ & 22 & 0.14 & 0.89 \\
\hline
\end{tabular}

Note: Numbers in parentheses are standard errors. $N$ is the number of individuals.

1993) compared with its effect on emergent, stationary bivalves, sand flat habitat would likely be considered suboptimal. We did not obtain measures of the foraging success of oystercatchers in these habitats, owing to the inaccessibility of the habitats in winter.

The long-term increase in search times at the Queen Sound oyster bed is most probably due to the decrease in oyster density over the same period. Handling time did not decrease over the long term, and this agrees with the expectation from Holling's disc equation, that if prey density declines without changes in prey size, handling time should remain constant (Piersma et al. 1995). This result is unlike earlier results of studies on European oystercatchers, where handling time decreased with increase in prey density (Wanink 
Table 6. Post-harvest changes in search time, handling time, and peck rate for all prey types combined and for oysters at Wachapreague.

\begin{tabular}{|c|c|c|c|c|c|c|}
\hline & \multicolumn{2}{|l|}{1993} & \multicolumn{2}{|l|}{1994} & \multirow[b]{2}{*}{$t_{\mathrm{s}}$} & \multirow[b]{2}{*}{$P$} \\
\hline & Mean & $N$ & Mean & $N$ & & \\
\hline \multicolumn{7}{|c|}{ All prey types combined } \\
\hline Search time $(s)$ & $72.54(12.25)$ & 13 & $47.30(10.73)$ & 30 & 2.79 & 0.005 \\
\hline Handling time $(\mathrm{s})^{*}$ & $20.20(3.36)$ & 12 & $9.69(1.53)$ & 29 & 3.60 & 0.0003 \\
\hline Peck rate (pecks/10 s) & $1.46(0.25)$ & 12 & $1.78(0.16)$ & 30 & -1.88 & 0.060 \\
\hline \multicolumn{7}{|c|}{ Oysters } \\
\hline Search time & $77.20(12.32)$ & 12 & $134.75(47.81)$ & 5 & 1.32 & 0.19 \\
\hline Handling time (s) & $21.13(3.54)$ & 11 & $22.14(5.67)$ & 4 & 0.20 & 0.84 \\
\hline Peck rate (no. of pecks/10 s) & $1.23(0.11)$ & 11 & $1.65(0.57)$ & 5 & 0.72 & 0.53 \\
\hline
\end{tabular}

Note: Numbers in parentheses are standard errors. $N$ is the number of individuals.

*In 1993 this handling time was made up primarily of oysters, whereas in 1994 oystercatchers were eating primarily worms.

Table 7. Yearly changes in oyster intake rate at Queen Sound and Wachapreague, and seasonal changes in oyster intake rate as well as yearly changes in mussel intake rate at the Queen Sound oyster bed.

\begin{tabular}{|c|c|c|c|c|}
\hline Comparison & $N$ & Mean $(\mathrm{mL} / 5 \mathrm{~min})$ & $t_{\mathrm{s}}$ & $P$ \\
\hline \multicolumn{5}{|c|}{ Oysters } \\
\hline \multicolumn{5}{|l|}{ Queen Sound } \\
\hline \multicolumn{5}{|l|}{ Yearly } \\
\hline Autumn 1993 & 107 & $6.15(0.60)$ & 0.06 & 0.95 \\
\hline Autumn 1994 & 102 & $6.27(0.68)$ & & \\
\hline \multicolumn{5}{|l|}{ Seasonal } \\
\hline Autumn (1993 and 1994) & 209 & $6.21(0.45)$ & 4.83 & $<0.0001$ \\
\hline Winter 1995 & 127 & $11.72(0.91)$ & & \\
\hline \multicolumn{5}{|l|}{ Wachapreague } \\
\hline Preharvest (autumn 1993) & 10 & $5.10(1.48)$ & 5.07 & $<0.0001$ \\
\hline Post harvest (autumn 1994) & 43 & $0.12(0.09)$ & & \\
\hline \multicolumn{5}{|c|}{ Mussels } \\
\hline \multicolumn{5}{|l|}{ Queen Sound } \\
\hline Autumn 1993 & 134 & $2.25(0.38)$ & 3.76 & 0.02 \\
\hline Autumn 1994 & 123 & $0.70(0.18)$ & & \\
\hline Winter 1995 & 138 & $0.16(0.16)$ & & \\
\hline
\end{tabular}

Note: Numbers in parentheses are standard errors. $N$ is the number of individuals.

and Zwarts 1985) because in that study, at higher prey densities, oystercatchers were thought to became more selective, choosing easily extracted prey (with shorter handling times; Piersma et al. 1995). In our study, oysters remained the predominant prey, and the consistent handling times were due to the consistent sizes of oysters selected. This lack of change in prey size over time is probably due to the fact that in 1979 the Queen Sound oyster bed was harvested, and the largest oysters were removed (D. Thornton, personal communication).

We did not find any long-term change in peck rate, possibly because the total number of possible prey items on the oyster bed, including living and dead oysters, did not change. If the oystercatchers could not separate living and dead bivalves by sight, they might be expected to peck at similar rates in 1995 and 1979.

\section{Seasonal changes}

The density and height of oysters decreased significantly from autumn to winter on the Queen Sound oyster bed. We attribute this decline primarily to oystercatcher predation, as although other potential predators, including the channeled whelk (Busycon canaliculatus), blue crab ( $\mathrm{Cal}$ linectes sapidus), and stone crab (Menippe mercenaria), were observed near the beds, we never observed them eating oysters, and their combined effect is probably minor. European oystercatchers depleted the cockles (Cerastoderma edule) and mussels ( $M$. edulis) throughout the winter in northwestern Europe (O'Connor and Brown 1977; GossCustard and Durell 1983, 1987). The black oystercatcher also had a major influence on the microdistribution of its limpet prey, reducing their numbers significantly (Frank 1982). 
Table 8. Yearly changes in the profitability of mussels and oysters, and seasonal changes in the profitability of oysters consumed at the Queen Sound oyster bed.

\begin{tabular}{|c|c|c|c|c|}
\hline Comparison & $N$ & $\begin{array}{l}\text { Mean profitability } \\
\qquad(\mathrm{mL} / \mathrm{s})\end{array}$ & $t_{\mathrm{s}}$ & $P$ \\
\hline \multicolumn{5}{|c|}{ Mussels } \\
\hline \multicolumn{5}{|l|}{ Yearly } \\
\hline Autumn 1993 & 48 & $0.07(0.01)$ & 0.40 & 0.69 \\
\hline Autumn 1994 & 20 & $0.09(0.03)$ & & \\
\hline \multicolumn{5}{|c|}{ Oysters } \\
\hline \multicolumn{5}{|l|}{ Yearly } \\
\hline Autumn 1993 & 116 & $0.12(0.06)$ & 0.42 & 0.67 \\
\hline Autumn 1994 & 110 & $0.12(0.07)$ & & \\
\hline \multicolumn{5}{|l|}{ Seasonal } \\
\hline Autumn (1993 and 1994) & 226 & $0.12(0.004)$ & 3.20 & 0.002 \\
\hline Winter 1995 & 162 & $0.15(0.01)$ & & \\
\hline
\end{tabular}

Note: N̦umbers in parentheses are standard errors. $N$ is the number of birds observed consuming each prey type.

Mussel density decreased seasonally, to virtual elimination in winter 1995. The mussel population on the Queen Sound bed was small enough in autumn that, again, depletion by oystercatchers seems the most probable cause. Disease or death due to exposure appears an unlikely cause of the decline because populations of mussels were attached to nearby cordgrass, where oystercatchers did not generally forage. Ribbed mussels are also extremely tolerant of freezing temperatures (Kanwisher 1955).

Densities of mussels and oysters in autumn remained approximately equal from 1993 to 1994 . These densities corresponded to very similar foraging behaviour by oystercatchers in the two autumn seasons, including similar volumes of the prey items eaten, similar search and handling times, and similar peck rates. This congruence suggests that some aspects of predator behaviour can be predicted on the basis of prey size and density (O'Connor and Brown 1977; Cayford and Goss-Custard 1990; Hutto 1990). However, peck rates of oystercatchers within the range of densities of prey found here may not indicate much about the distribution of prey, because peck rates were similar for both mussels and oysters and similar to peck rates of birds foraging on worms in Wachapreague, and these three food items have very different densities in the study area (see also "Long-term changes").

The only change that we observed from one autumn to the next was a significant decline in intake rates of mussels. As we recorded an effect of the state of the tide on the choice of mussels over oysters, we suggest that possible differences in the pattern of rising and falling tides, due to changes in wind direction and speed, may have resulted in the decline in intake rate of mussels in autumn 1994. Although both mussels and oysters are filter feeders, mussels can remain gaping longer in the absence of water than oysters can (Lent 1968). Overall intake rates (for both major prey types) were similar in the two autumn seasons despite the lower intake rate of mussels in 1994, presumably because mussels comprised only about $20 \%$ of all prey items.

The general congruence between search times and prey densities that we observed between the two autumn seasons, and between oysters and mussels in autumn, breaks down when we examine the behaviour of oystercatchers at the Queen sound oyster bed in winter. Oystercatchers ate larger oysters in winter than in autumn, although we found that oysters on the beds were significantly larger in autumn than in winter. The foraging birds also spent less time searching for larger oysters. Therefore, the oystercatchers must have been selectively choosing larger oysters over smaller ones in winter. European oystercatchers also chose the largest prey during the coldest months (Cayford and Goss-Custard 1990), presumably because these resulted in a higher intake rate. The question, then, is why oystercatchers chose smaller prey in autumn even though it apparently took more time to search for these prey.

Our results indicate that although handling times were longer for the larger oysters, intake rates were also much higher. Profitability of oysters also increased because the larger volume of the oysters chosen in winter more than compensated for the increase in handling time. As oysters grow very little from November to February (Dame 1972), we presume that the larger oysters were available on the oyster bed in autumn. We suggest that this deviation from expectation based on optimal foraging theory (maximizing energy intake per unit handling time or profitability) may be partly explained by oystercatchers choosing smaller oysters with shorter handling times in the autumn, because of the action of kleptoparasitic gulls. Gulls' success in stealing prey appeared to be related to handling times of prey, and they stole prey more actively in autumn than in winter (Tuckwell and Nol 1997).

Significantly more oystercatchers foraged on the Queen Sound bed during winter than in autumn, and again we think that this is because oysters and mussels were much more available in sand flat habitats than submergent bivalves, which burrow deeply and consequently require much longer handling times (Zwarts and Wanink 1993). Diet breadth was greater in both autumn seasons than in winter 1995. Oystercatchers may also rely more heavily on alternative prey during autumn to avoid intraspecific competition and inter- 
ference (Goss-Custard and Durrell 1987; Tuckwell and Nol 1997).

We found no evidence for an increase in the amount of time spent foraging in winter, contrary to our prediction (Maron and Myers 1985), at least when we compared the time budgets of oystercatchers foraging on the oyster beds in the two seasons. When we examined the population overall, including the birds that foraged on the sand flats, the oystercatchers spent more time roosting in autumn than in winter. We suggest that examining time budgets is misleading as a proxy for food availability (Martin 1986) in this species because we also found that on two occasions in subzero weather, oystercatchers refrained from foraging at all. Therefore, more roosting and less foraging can be interpreted as evidence for both greater (i.e., satisfied their energy requirements in a shorter period of time) and less availability of food (i.e., restricted their activities to save energy for maintenance; Evans 1976; Davidson 1981).

\section{Preharvest and post harvest}

Oyster density decreased dramatically on the Wachapreague bed as a result of the 1994 commercial harvest, but oystercatchers continued to forage there and found a small number of remaining oysters. We do not have measurements of the remaining oysters, but given that handling times did not decline significantly, we suggest that their size did not decline, as oyster harvesters often leave large oysters to provide seed for future harvests. Not surprisingly, intake rates of oysters declined precipitously from autumn 1993 to autumn 1994. In response to the harvest, diet breadth increased to include a large number of worms, but was still low compared with the diet breadth calculated for the Chincoteague area during the same time period. As a result of the switch to worms, search and handling times declined, because worms were numerous and easily swallowed.

None of the foraging parameters measured specifically for oysters altered as a result of the harvest, although there was a trend (which we had expected) towards longer search times post harvest. The long-term effects on the oystercatchers of a sudden 10 -fold decline in their prey are predicted to be movement to other areas and changes in the distribution of the birds. Oysters in Wachapreague contained a higher proportion of lipids than those in Chincoteague (M. Luckenbach, Virginia Institute of Marine Sciences, personal communication), and recovery of the bed after the breeding season, when only few oystercatchers forage on oysters, may, given the rapid growth rate of oysters, mean fidelity to this foraging location. Only examining a marked population will allow us to determine whether this hypothesis is correct.

Oystercatcher populations appear to have been maintained along the Virginia coast, at least since 1968 (Nol and Humphrey 1994), and in the New England states, breeding populations of this species appear to be increasing (Humphrey 1990). Behavioural flexibility is a key feature of widespread species (Klopfer and MacArthur 1960; Greenberg 1990), and is also a feature of the European oystercatcher, which is able to forage in both agricultural and coastal environments (Heppleston 1972), although in the former environment, pairs are not as successful as in the latter (Briggs 1984). The behavioural flexibility that we observed in foraging American oystercatchers in the face of three sources of prey decline indicates that this species will likely be able to maintain its population size, given even relatively unhealthy stocks of commercial oysters, by increasing their size selectivity in winter and concentrating their search on the most profitable oysters. Additional study of populations foraging solely on noncommercially harvested shellfish, with their slower growth rates and greater seasonal variability in availability, might indicate lower rates of intake by foraging birds and, possibly, starvation (Clark 1993). This would indicate the degree to which commercial oyster beds are reducing natural over-winter mortality in this species. Further, comparing recruitment into breeding populations of oystercatchers in the 1970s and 1980s with the present level would be an additional method of determining whether a declining winter prey base has consequences for the population.

\section{Acknowledgements}

We thank Bruce McCulloch, Dawn Brenner, Rudy Cashwell, and Mark Luckenbach for their assistance in the field. Lodging and hospitality were graciously provided by Cynthia and Edward Risley. Funding was provided by the Joy Foundation, Chincoteague, Va., and Trent University. M. Blouin from Oregon State University provided office space to E.N. We also thank Michael Cadman, without whose work this study would not have been possible.

\section{References}

Andrews, J.D. 1988. Epizootiology of the disease caused by the oyster pathogen, Perkinsus marinus, and its effect on the oyster industry. Am. Fish. Soc. Spec. Publ. No. 18. pp. 47-63.

Boates, J.S., and Goss-Custard, J.D. 1992. Foraging behaviour of oystercatchers, Haematopus ostralegus, specializing on different species of prey. Can. J. Zool. 70: 2398-2404.

Briggs, K. 1984. The breeding ecology of coastal and inland oystercatchers in North Lancashire. Bird Study, 31: 141-147.

Cadman, M.D. 1980. Age-related foraging efficiency of the American Oystercatcher (Haematopus palliatus). M.Sc. thesis, University of Toronto, Toronto, Ontario.

Cayford, J.T., and Goss-Custard, J.D. 1990. Seasonal changes in the size selection of mussels, Mytilus edulis, by oystercatchers, Haematopus ostralegus: an optimality approach. Anim. Behav. 40: 609-624.

Clark, N. 1993. Wash oystercatchers starving. Wader Study Group Bull. No. 70. pp. 51-52.

Connors, P.G., Myers, J.P., Connors, C.S.W., and Pitelka, F.A. 1981. Interhabitat movements by Sanderlings in relation to foraging profitability and the tidal cycle. Auk, 98: 49-64.

Cresswell, W. 1994. Age-dependent choice of Redshank (Tringa totanus) feeding location: profitability or risk? J. Anim. Ecol. 63: $589-600$.

Cummins, K.W., and Wuycheck, J.C. 1971. Caloric equivalents for investigations in ecological energetics. Mitt. Int. Ver. Theor. Angew. Limnol. 18: 1-158.

Dame, R.F. 1972. The ecological energies of growth, respiration and assimilation in the American oyster, Crassostrea virginica. Mar. Biol. (Berl.), 17: 243-250.

Davidson, N.C. 1981. Survival of shorebirds (Charadrii) during severe weather: the role of nutritional reserves. In Feeding and survival strategies of estuarine organisms. Edited by N.V. Jones and W.J. Wolff. Plenum Press, London. pp. 179-192.

Davidson, N.C., and Evans, P.R. 1983. Mortality of redshanks and oystercatchers from starvation during severe weather. Bird Study, 29: 183-188. 
Drew, G.A. 1907. The habits and movements of the razor clam, Ensis directus. Biol. Bull. (Woods Hole, Mass.), 12: 127-140.

Dugan, P.J. 1981. The importance of nocturnal foraging in shorebirds: a consequence of increased invertebrate prey activity. In Feeding and survival strategies of estuarine organisms. Edited by N.V. Jones and W.J. Wolff. Plenum Press, London. pp. $251-260$.

Ens, B. J., Kersten, M., Brenninkmeijer, A., and Hulscher, J.B. 1992. Territory quality, parental effort and reproductive success of oystercatchers (Haematopus ostralegus). J. Anim. Ecol. 61: $703-715$.

Evans, P.R. 1976. Energy balance and optimal foraging strategies in shorebirds: some implications for their distributions and movements in the non-breeding season. Ardea, 64: 117-139.

Figueras, A.J., and Fisher, W.S. 1988. Ecology and evolution of bivalve parasites. Am. Fish. Soc. Spec. Publ. No. 18. pp. $130-137$.

Frank, P.W. 1982. Effects of winter feeding on limpets by Black Oystercatcher, Haematopus bachmani. Ecology, 63: 1352-1362.

Goss-Custard, J.D., and Durell, S.E.A. le V. dit. 1983. Individual and age differences in the feeding ,ecology of oystercatchers, Haematopus ostralegus, wintering on the Exe estuary, Devon. Ibis, 125: 155-171.

Goss-Custard, J.D., and Durell, S.E.A. le V. dit. 1987. Age-related effects in oystercatchers, Haematopus ostralegus, feeding on mussels, Mytilus edulis. III. The effect of interference on overall intake rate. J. Anim. Ecol. 56: 549-558.

Goss-Custard, J.D., Caldow, R.W.G., Clarke, R.T., Durell, S.E.A. le V. dit, and Sutherland, W.L. 1995a. Deriving population parameters from individual variations in foraging behaviour. I. Empirical game theory distribution model of oystercatchers Haematopus ostralegus feeding on mussels Mytilus edulis. J. Anim. Ecol. 64: 265-276.

Goss-Custard, J.D., Caldow, R.W.G., Clarke, R.T., and West, A.D. $1995 b$. Deriving population parameters from individual variations in foraging behaviour. II. Model tests and population parameters. J. Anim. Ecol. 64: 277-289.

Goss-Custard, J.D., Cayford, J.T., Boates, J.S., and dit Durell, S.E.A. le V. 1987. Field tests of the accuracy of estimating prey size from bill length in oystercatcher, Haematopus ostralegus, eating mussels, Mytilus edulis. Anim. Behav. 35: 1078- 1083.

Greenberg, R. 1990. Ecological plasticity, neophobia, and resource use in birds. Stud. Avian Biol. 13: $431-437$.

Haskin, H.H., and Andrews, J.D. 1988. Uncertainties and speculation about the life cycle of the eastern oyster pathogen, Haplosporidium nelsoni: MSX. Am. Fish. Soc. Spec. Publ. No. 18. pp. 5-22.

Heijl, S.J., Verner, J., and Bell, G.W. 1990. Sequential versus initial observations in studies of avian foraging. Stud. Avian Biol. 13: $166-173$.

Heppleston, P.B. 1972. The comparative breeding ecology of oystercatchers (Haematopus ostralegus L.) in inland and coastal habitats. J. Anim. Ecol. 41: 23-50.

Holling, C.S. 1959. Some characteristics of simple types of predation and parasitism. Can. Entomol. 91: 385-398.

Hulscher, J.B. 1989. Mortality and survival of Oystercatchers Haematopus ostralegus during severe winter conditions. Limosa, 62: $177-182$.

Hulscher, J.B., and Ens, B.J. 1992. Is the bill of the male oystercatcher a better tool than the bill of the females? Neth. J. Zool. 42: $85-100$.

Hurlbert, H.S. 1978. The measurement of niche overlap and some relatives. Ecology, 59: 67-77.

Humphrey, R.C. 1990. Status and range expansion of the American Oystercatcher on the Atlantic coast. Trans. Northeast Sect. Wildl. Soc. 47: 54-61.
Hutto, R.L. 1990. Measuring the availability of food resources. Stud. Avian Biol. 13: 20-28.

Kanwisher, J.W. 1955. Freezing in intertidal animals. Biol. Bull. (Woods Hole, Mass.), 109: 56-63.

Kaspari, M., and Joern, A. 1993. Prey choice by three insectivorous birds: reevaluating opportunism. Oikos, 68: 414-430.

Klopfer, P.H., and MacArthur, R.H. 1960. Niche size and faunal diversity. Am. Nat. 94: 292-300.

Krebs, C.J. 1989. Ecological methodology. HarperCollins Publishers Inc., New York.

Lent, C.M. 1968. Air-gaping by the ribbed mussel, Modiolus demissus (Dillwyn): effects and adaptive significance. Biol. Bull. (Woods Hole, Mass.), 134: 60-73.

Levings, S.C., Garrity, S.D., and Ashkenas, L.R. 1986. Feeding rates and prey selection of oystercatchers in the Pearl Islands of Panama. Biotropica, 18: 62-71.

Maron, J.L., and Myers, J.P. 1985. Seasonal changes in feeding success, activity patterns, and weights of nonbreeding Sanderlings (Calidris alba). Auk, 102: 580-586.

Martin, T.E. 1986. Competition in breeding birds: on the importance of considering processes at the level of the individual. Curr. Ornithol. 4: $181-210$.

Nol, E. 1989. Food supply and reproductive performance of the American Oystercatcher in Virginia. Condor, 91: 429-435.

Nol, E., and Humphrey, R.C. 1994. American Oystercatcher (Haematopus palliatus). In The birds of North America. No. 82. Edited by A. Poole and F. Gill. The Academy of Natural Sciences, Philadelphia, and The American Ornithologists' Union, Washington, D.C.

O'Connor, R.J., and Brown, R.A. 1977. Prey depletion and foraging strategy in the oystercatcher, Haematopus ostralegus. Oecologia, 27: 75-92.

Piersma, T., van Gils, J., de Goeij, P., and van der Meer, J. 1995. Holling's functional response model as a tool to link the food-finding mechanism of a probing shorebird with its spatial distribution. J. Anim. Ecol. 64: 493-504.

Roberts, D., Rittschof, D., Gerhart, D.J., Schmidt, A.R., and Hill, L.G. 1988. Vertical migration of the clam Mercenaria mercenaria (L.) (Mollusca: Bivalvia). Environmental correlates and ecological significance. J. Exp. Mar. Biol. Ecol. 126: 271 - 280.

Shick, J.M., Widdows, J., and Gnaiger, E. 1988. Calorimetric studies of behavior, metabolism and energetics of sessile intertidal animals. Am. Zool. 28: 161-181.

Sindermann, C.J. 1970. Principal diseases of marine fish and shellfish. Vol. 2. 2nd ed. Academic Press, Inc., San Diego, California.

Stephens, D.W., and Krebs, J.R. 1986. Foraging theory: monographs in behavior and ecology. Princeton University Press, Princeton, N.J.

Tuckwell, J., and Nol, E. 1997. Intra- and interspecific interactions of foraging American oystercatchers on an oyster bed. Can. J. Zool. 75: 182-187.

Wanink, J., and Zwarts, L. 1985. Does an optimally foraging oystercatcher obey the functional response? Oecologia, 67: $98-106$.

Woodin, S.A. 1974. Polychaete abundance patterns in a marine soft-sediment environment: the importance of biological interactions. Ecol. Monogr. 44: 171- 187.

Zwarts, L., and Wanink, J. 1993. How the food supply harvestable by waders in the Wadden Sea depends on the variation in energy density, body weight, biomass, burying depth and behaviour of tidal-flat invertebrates. Neth. J. Sea Res. 31: 441-476. 